\title{
Pengaruh Doping Ion Alumunium pada Kurva Serapan FTIR dan Struktur Kristal Nanopartikel Kobalt Ferit Hasil Kopresipitasi
}

\author{
Anisa Khoiriah,* Utari, dan Budi Purnama \\ Jurusan Fisika, Fakultas Matematika dan Ilmu Pengetahuan Alam, \\ Universitas Sebelas Maret, Jl. Ir. Sutami 36A Kentingan Jebres, Surakarta, 57126
}

\begin{abstract}
Intisari
Telah dipelajari pengaruh doping ion alumunium pada nanopartikel cobalt ferrite hasil fabrikasi metode kopresipitasi. Ion alumunium dipilih mengingat jari-jari kovalennya sebanding dengan jari-jari cobalt. Hasil analisis FTIR menunjukkan pada tetrahedral site, force constant berubah sebesar $0,23 \mathrm{~N} / \mathrm{m}$ akibat doping ion alumunium. Berdasar analisis XRD pada puncak tertinggi, ukuran kristalit tanpa dan dengan doping alumunium adalah masing masing 57,75 $\mathrm{nm}$ menjadi 46,2 $\mathrm{nm}$. Perubahan ukuran kristalit ini disinyalir akibat substitusi ion cobalt dengan ion alumunium dengan jari-jari kovalen alumunium lebih kecil dibanding ion cobalt.
\end{abstract}

\section{ABSTRACT}

It has been studied the aluminum doping effect on co-precipitated cobalt ferrite nanoparticles. Aluminum ion was chosen considering covalent radius comparable to the radius of cobalt. The analysis of FTIR results showed that the change of constant force without and with doping aluminum ion on tetrahedral site was $0.23 \mathrm{~N} / \mathrm{m}$. The calculated of crystallite size from the strongest peak of XRD pattern indicated that the crystallite size reduces from 57.75 to $46.20 \mathrm{~nm}$ after doped aluminum. The change of the crystallite size was presumably due to the substitution of cobalt ions with aluminum ions since the aluminum covalent radius was smaller than cobalt ions.

KATA KUNCI: cobalt ferrite, aluminum ion, co-precipitation http://dx.doi.org/10.12962/j24604682.v13i2.2298

\section{PENDAHULUAN}

Dalam kurun waktu satu dasawarsa terakhir, nanopartikel magnetik menjadi salah satu objek kajian penelitian menarik mengingat karakteristik fisis yang unggul dibandingkan dari fase bulk [1, 2]. Cobalt ferrite $\left(\mathrm{Co}_{2} \mathrm{Fe}_{4}\right)$ menjadi bahan kajian utama dari sekian banyak nano partikel magnetik, karena karakteristik magneik tidak hilang ketika nano partikel berukuran kurang dari $100 \mathrm{~nm}$. Kehadiran domain magnetik tunggal pada sebuah nano partikel merupakan target para peneliti mengingat mampu membuka peluang aplikasi dibidang kedokteran, khususnya sebagai agen kontras pada MRI maupun pembawa obat pada sistem pengobatan kanker [3].

Cobalt ferrite tergolong spinel oksida, dengan ion $\mathrm{Co}^{2+}$ menempati di octahedral site dan ion $\mathrm{Fe}^{3+}$ menempati tetrahedral site dan octahedral sites [4]. Saat ini, ragam sintesis cobalt ferrite yang telah dikembangkan antara lain kopresipitasi [5], sol-gel, mikoemulsi, autocombution [6] dan reverse kopresipitasi [7]. Metode kopresipitasi merupakan salah satu metode yang banyak digunakan pada sintesis nanopartikel cobalt ferit [8]. Metode ini menghasilkan distribusi partikel yang relatif sama dan dapat dilakukan pada kondisi lingkun-

\footnotetext{
*E-MAIL: anisakhoiriah1994@gmail.com
}

gan normal. Guna memodifikasi karakteristik fisis cobalt ferrite, telah banyak dilakukan penelitian tentang penambahan bahan atau doping pada sintesis nanopartikel cobalt ferrite seperti menggunakan ion logam transisi $\mathrm{Ni}, \mathrm{Al}$ maupun logam tanah jarang Sr, Gd [9].

Dalam paper ini, studi pendahuluan sintesis nanopartikel cobalt ferrit dengan doping ion alumunium disajikan. Sampel disintesis menggunakan metode kopresipitasi dilanjutkan dengan anil. Sampel nano partikel yang diperoleh dikarakterisasi dengan FTIR dan XRD.

\section{METODOLOGI PENELITIAN}

Tahapan penelitian ini dibagi menjadi 3 tahap yaitu sintesis prekursor, anil dan karakterisasi hasil sintesis. Sintesis prekursor dimulai dengan perhitungan stokiometri $\mathrm{Fe}\left(\mathrm{NO}_{3}\right)_{3} .9 \mathrm{H}_{2} \mathrm{O}$ sebanyak $0,019 \mathrm{~mol}, \mathrm{Co}\left(\mathrm{NO}_{3}\right)_{2} \cdot 6 \mathrm{H}_{2}$ sebanyak 0,01 mol dan $\mathrm{Al}\left(\mathrm{NO}_{3}\right)_{3} \cdot 9 \mathrm{H}_{2} \mathrm{O} 0,001 \mathrm{~mol}$. Kemudian ketiga bahan tersebut dilarutkan dalam $200 \mathrm{ml}$ RO-des, larutan asam ini kemudian disebut larutan titrasi. Tahapan kemudian adalah pembuatan larutan basa yaitu $\mathrm{NaOH}$ 4,8 M. Selanjutnya, larutan logam diteteskan sedikit demi sedikit (ditritrasi) ke dalam larutan $\mathrm{NaOH}$ yang dijaga pada temperatur $85^{\circ} \mathrm{C}$. Proses titrasi berlangsung kurang lebih 2 jam dan selama titrasi distirrer $1500 \mathrm{rpm}$. Setelah dilakukan proses pengendapan selama 24 jam, hasil dicuci hingga bersih dengan alkohol dan RO-des. Proses hidrolisis pada oven temperatur 


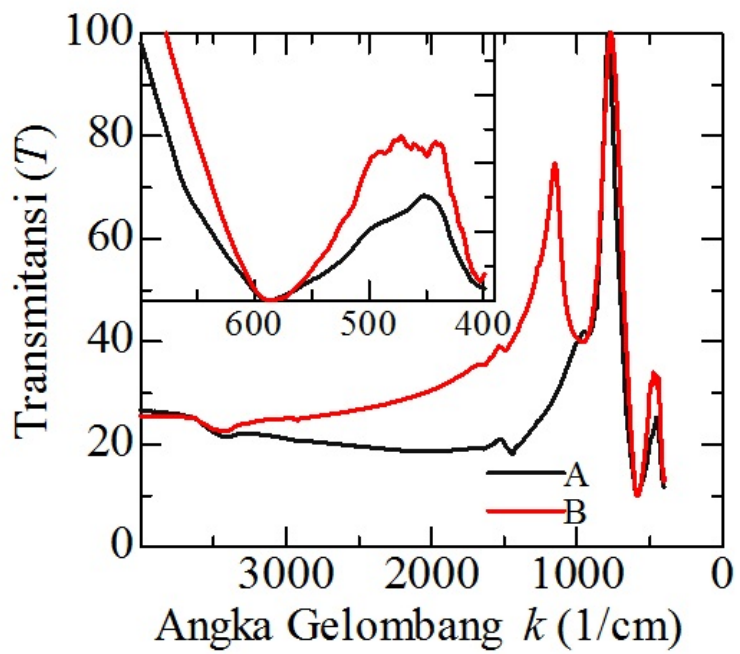

Gambar 1: Kurva karakterisasi spektrum FTIR skema A (cobalt ferrite tanpa doping alumununium) dan skema $\mathrm{B}$ (cobalt ferrite dengan alumunium $0,1 \mathrm{~mol}$ ) temperatur annealing $1000^{\circ} \mathrm{C}$.

$100^{\circ} \mathrm{C}$ selama 12 jam adalah prosedur selanjutnya, hasil ini disebut prekursor. Selanjutnya prekursor dilakukan proses annealing pada temperatur $1000^{\circ} \mathrm{C}$ selama 5 jam. Sampel cobalt ferrite yang diperoleh kemudian dikarakterisasi dengan menggunakan FTIR dan XRD.

\section{HASIL DAN PEMBAHASAN}

\section{Analisis FTIR}

Gambar 1 menunjukkan hasil spektrum FTIR dari sampel nanopartikel cobalt ferrite, yaitu spektrum A (tanpa doping $\mathrm{Al}$ ) dan spektrum B (dengan doping Al sebesar 10\% mol Co). Teramati dengan jelas dari Gambar 1 bahwa terdapat tipikal puncak serapan. Puncak serapan pertama teramati pada angka gelombang/wavenumber $\mathrm{k}=3418 \mathrm{~cm}^{-1}$. Hal ini menunjukkan keberadaan vibrasi bending H-O-H. Kemudian kurva FTIR memperlihatkan serapan pada wavenumber $\mathrm{k}=900-1400 \mathrm{~cm}^{-1}$, puncak serapan ini menunjukkan keberadaan gugus C-O. Selanjutnya, kurva serapan, menunjukkan tipikal serapan yang tajam pada $586,89 \mathrm{~cm}^{-1}$ dan 584,46 $\mathrm{cm}^{-1}$ untuk masing-masing sampel A dan sampel B. Tipikal puncak serapan ini merupakan struktur oksida cobalt ferrite. Hasil ini sesuai dengan hasil penelitian yang dilaporkan Safi et al.(2015) [4]. Angka gelombang hanya tereduksi sebesar 2,43 $(=586,89-584,46)$. Hal ini dapat diprediksi bahwa ion alumunium mengisi salah satu posisi ion cobalt pada struktur oksida ferit secara natural. Kesesuaian substitusi ion ini mengingat jari-jari kovalen atom alumunium (121 pm) dan cobalt adalah masing-masing $121 \mathrm{dan} 126 \mathrm{pm}$.

Pergeseran puncak serapan pada spektrum FTIR di sekitar angka gelombang $600 \mathrm{~cm}^{-1}$ akibat tambahan doping ion alumunium mengindikasikan perubahan force constant pada tetrahedral site. Nilai force constant ini dapat dihitung menggunakan persamaan $\mathrm{k}_{t}=7,62 \mathrm{M}_{1} \times \mathrm{k}_{1}^{2} \times 10^{-7} \mathrm{~N} / \mathrm{m}$, den-

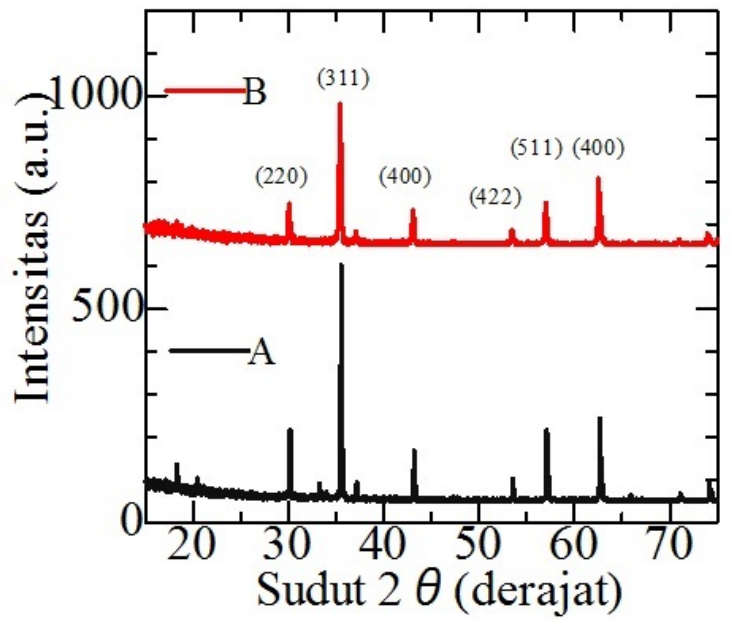

Gambar 2: Kurva karakterisasi spektral XRD pada cobalt ferrite tanpa doping alumunium(A) dan doping 0,1 mol (B) dengan temperatur annealing $1000^{\circ} \mathrm{C}$.

TABEL I: Perbandingan ukuran kristalit, parameter $\alpha$, dan densitas dari sampel skema A dan dan skema B.

\begin{tabular}{lcc}
\hline \hline Parameter & \multicolumn{2}{c}{ S a m p e l } \\
& A & B \\
\hline Ukuran kristalit (nm) & 57,75 & 46,2 \\
Parameter sel (a) & 8,37 & 8,38 \\
Densitas $\left(\mathrm{g} / \mathrm{cm}^{3}\right)$ & 5,31 & 5,27 \\
\hline \hline
\end{tabular}

gan $\mathrm{M}_{1}$ adalah massa molekul kation di tetrahedral site dan $\mathrm{k}_{1}$ adalah angka gelombang. Hasil perhitungan force constant untuk sampel A sebesar 28,60 N/m dan sampel B sebesar $28,37 \mathrm{~N} / \mathrm{m}$, sehingga pada tetrahedral site besar force constant berubah sebesar 0,23 N/m (=28,60-28,37). Perubahan yang kecil ini semakin menyakinkan bahwa ion alumunium dapat mengganti ion cobalt pada oksida cobalt ferit dengan baik.

\section{Analisis XRD}

Karakteristik spektral XRD dalam Gambar 2 ditunjukkan 6 puncak bersesuaian dengan sudut $2 \theta$ dari sampel cobalt ferrite tanpa doping atau dengan doping alumunium. Hasil ini bersesuaian dengan ICDD nomor 2210086 yang merupakan struktur (inverse spinel) face center cubic (fcc) cobalt ferrite yang sesuai dengan penelitian sebelumnya. Puncak tertinggi XRD diperoleh pada sudut $2 \theta=35,53^{\circ}$ untuk sampel A dan $2 \theta=35,43^{\circ}$ untuk sampel B. Kecilnya perubahan sudut puncak antara sampel tanpa dan dengan doping disinyalir bahwa ion alumunium dapat menggantikan posisi ion cobalt dalam struktur invers spinel.

Penggunakan data puncak tertinggi untuk menghitung ukuran kristalit dengan persamaan Scherer, sedangkan perhitungan parameter jarak antar kisi $\alpha$ dan densitas disajikan pada Tabel I.

Berdasarkan data indeks miller hkl didapatkan ukuran kristalit, parameter $\alpha$, dan densitas dari sampel skema A dan B ditunjukkan pada Tabel I. Ukuran kristalit sampel A memiliki 
nilai kristalit sebesar $57,75 \mathrm{~nm}$ dan sampel B memiliki nilai kristalit yang lebih kecil yaitu 46,2 nm. Perhitungan parameter $\alpha$ pada skema A lebih kecil daripada skema B yaitu 8,37 $\mathrm{nm}$ dan $8,38 \mathrm{~nm}$. Densitas yang dihasilkan juga menyatakan bahwa skema A memiliki densitas yang lebih besar yaitu 5,31 $\mathrm{nm}$. Hal ini semakin meyakinkan bahwa substitusi ion cobalt dengan ion alumunium terjadi pada sampel B.

\section{SIMPULAN}

Studi pendahuluan pengaruh doping almunium pada nanopartikel cobalt ferrite telah didiskusikan pada paper ini.
Hasil FTIR menegaskan terjadi perubahan force constant pada tetrahedral site. Selanjutnya, berdasarkan hasil analisis XRD, penambahan doping ion alumunium menyebabkan perubahan ukuran kristal. Selanjutnya memodifikasi parameter kisi dan densitas sampel yang diperoleh.
[1] C. Buzea, I.I.P. Blandino, K. Robbie, Biointerphases, 2(4), MR17- MR172 (2007).

[2] E.A. Velasquez, et al., J. Magn. Magn. Mater., 348, 154-159 (2013).

[3] A. Wirmanda, T. Dahlan, R. Nurlaela, Sintesis dan penentuan sifat struktur cobalt ferrite $\left(\mathrm{CoFe}_{2} \mathrm{O}_{4}\right)$ menggunakan metode kopresipitasi dengan memvariasikan dengan memvariasikan temperatur sintesis, Program sarjana Universitas Hasanuddin. Makasar, 2015.

[4] R. Safi, A. Ghasemi, S. R. Razavi, M. Travousi, J. Magn. Magn. Mater., 396, 288-294 (2015).
[5] F. Huixia, et al., J. Magn. Magn. Mater., 356, 68-72, 2014.

[6] S.J. Kotnala, Ferrite Materials: Nano to spintronic regime, in Handbook of Magnetic Materials (ed. K.H.J. Buschow, vol. 23, New Delhi, India, 2015).

[7] K. Maaz, et al., J. Magn. Magn. Mater., 321, 1838-1842 (2009).

[8] E.A. Setiadi, et al., Indonesian Journal of Applied Physics, 3(1), 1-8 (2013).

[9] H.M. Zaki, et al., J. Magn. Magn. Mater., 401, 1027-1032 (2016). 